\title{
The use of the Ugandan initial grain sorghum forms in the hybridization of the sorghum varieties for forage and food
}

\author{
Vladimir Kovtunov ${ }^{1, *}$ and Natalia Kovtunova ${ }^{1}$ \\ ${ }^{1}$ Agricultural Research Center “Donskoy”, Nauchny Gorodok, 3, Zernograd, Rostov region, 347740, \\ Russia
}

\begin{abstract}
The problem to develop new early maturing grain sorghum varieties adapted to mechanized harvesting with high productivity and feed advantages, is of great urgency. The purpose of the current work was to study the inheritance of the main economically valuable traits in the first generation hybrids developed in the hybridization between samples of different ecological and geographical origin. In the first generation hybrids Zernogradskoe 88 x Seso 1 and Zernogradskoe $88 \times$ Narosorg 1, there was identified the improvement of 1000-grain weight, number of grains per panicle, and length of a peduncle in comparison with the initial parental forms. In the hybrid combination obtained as a result of hybridization of the varieties Zernogradskoe 88 and Seso 3 there was not identified any positive manifestation of heterosis for the breeding process in the main studied traits. According to the trait 'plant height' in all combinations, there was identified overdominance of high-growing forms. According to the protein percentage in grains there was established depression or dominance of lower values of the trait. The inheritance of the trait 'length of vegetation period' in the studied hybrids corresponded to the partial dominance of both lower and higher values of the trait.
\end{abstract}

\section{Introduction}

The problem to form a solid raw material basis for feeding farm animals in conditions of increasing aridity of the climate is currently of the greatest importance. The solution to this problem is possible by increasing the sown area of agricultural crops which are tolerant to the negative impact of soil and climatic conditions and are capable to form high and stable yields. Grain sorghum is among this group of grain crops.

Sorghum is considered one of the most drought-resistant and heat tolerant agricultural crops in world agriculture [1]. In terms of world grain production, sorghum ranks fifth after wheat, rice, corn and barley $[2,3]$.

Sorghum grain is widely used all over the world. It is eaten, used in feed production and in the production of alcoholic beverages. In many parts of Africa, as well as in Arabic cuisine, sorghum is used for cooking soups, cereals and tortillas. Popcorn is made from sorghum. Since 2000 sorghum has been increasingly used in bakery and as groats for

*Corresponding author: kowtunow85@mail.ru 
gluten-free diets. In China sorghum is the most important ingredient in alcoholic beverages, and in the United States of America sorghum is used in the production of gluten-free beer [4].

The chemical composition and nutritional value of sorghum grain is compared to such forage crop as maize. Sorghum is also a good feed for farm animals [5,6].

The widespread introduction of sorghum is constrained by the insufficient number of early maturing varieties and hybrids. Therefore, special attention in grain sorghum breeding should be paid to the estimation of the length of vegetation period [7-9]. The samples with more than 100 days of vegetation under the conditions of the North Caucasus do not always reach the standard grain moisture content; therefore, the costs for drying seeds increase. Thus, the development of early maturing varieties is one of the main tasks in sorghum breeding. Productivity improvement is an equally important problem for all crops, including sorghum. The main traits that determine sorghum productivity are "number of grains per panicle and 1000-grain weight $[10,11]$. Improvement of these traits will result in sorghum productivity increase. However, productivity improvement takes place in the case of increase of the period before complete grain maturity. In addition, the developed varieties must be technologically advanced, that is, have certain morphological characteristics. In grain sorghum breeding, plant height is one of the main traits $[12,13]$. Breeding work should be aimed at developing low-growing varieties, as they are more resistant to lodging and are adapted to mechanized cultivation. The most optimal height is considered from 90 to $120 \mathrm{~cm}$. To improve mechanized sorghum harvesting, the trait 'length of a peduncle' is of great importance. An increase in the distance between a flag leaf and a panicle results in foliage mass decrease in the grain during combine harvesting and reduces its moisture. In addition to morphological traits in agricultural crop breeding, attention should be paid to biochemical indicators that determine the feed and nutritional values of grain, such as protein and starch $[14,15]$.

Thus, the problem to develop new early maturing grain sorghum varieties adapted to mechanized harvesting with high productivity and feed advantages, is of great urgency.

The purpose of the current work was to study the inheritance of the main economically valuable traits in the first generation hybrids developed in the hybridization between samples of different ecological and geographical origin.

\section{Materials and methods}

The study was carried out at the Federal State Budget Scientific Institution "Agricultural Research Center "Donskoy", (Zernograd, Rostov Region) in 2019-2020. The soil of the experimental plot was ordinary carbonate blackearth (chernozem), with $3.6 \%$ of humus in the arable layer. The weather conditions during the years of study were very dry. The value of the hydrothermal coefficient for the vegetation period of the crop in 2019 was 0.63 , in 2020 it was 0.68 .

The objects of the study were the first generation hybrids and their parental forms.

The subjects of the study were the main economically valuable traits (1000-grain weight, number of grains per panicle, plant height, length of a peduncle, length of a vegetation period), as well as the main biochemical parameters affecting the feed value of grain (protein and starch percentage).

The trial, the observations and records were carried out according to the Methodology of the State Variety Testing and the Methodology of a field trial. The content of the main nutrients was estimated by generally accepted methods, namely Kjeldahl method was utilized for raw protein estimation; starch content was estimated by the Evers polarimetric method.

The dominance degree was estimated by the formula: 


$$
h p=\frac{\left(F_{1}-P_{\text {aver }}\right)}{\left(P_{l \arg e}-P_{\text {aver }}\right)}
$$

where

$h p$ is a dominance degree;

$P_{\text {large }}$ is a parental form with large value of trait;

$P_{\text {aver }}$ is a parental form with average value of trait.

The value of true and hypothetical heterosis was estimated by the formulas:

$$
\begin{array}{r}
H_{\text {hyp }}=\frac{\left(F_{1}-P_{\text {aver. }}\right) \times 100}{P_{l \text { arge }}} \\
H_{\text {true }}=\frac{\left(F_{1}-P_{\text {larg } e}\right) \times 100}{P_{l \text { arg } e}}
\end{array}
$$

where

$H_{\text {hyp }}$ is a hypothetical heterosis;

$H_{\text {true }}$ is a true heterosis;

$F_{l}$ is a value of trait of the first generation hybrid;

$P_{\text {aver. }}$ is a parental form with average value of trait;

$P_{\text {large }}$ is a parental form with large value of trait.

In the identified hybrid combinations, manifestation of the inheritance types was estimated by the value of the dominance degree: $h p>1.0$ was overdominance; $h p<-1.0$ was depression; $0<\mathrm{hp}<0.5$ was partial dominance; $\mathrm{hp}=0.5$ was semi-dominance; $0.5<\mathrm{hp}<1.0$ was incomplete dominance; $\mathrm{hp}=1.0$ was complete dominance.

\section{Results}

The hybridization carried out on a fertile basis resulted in the development of the first generation hybrids. The forms of different ecological and geographic origin were utilized as parental forms. The grain sorghum variety Zernogradskoe 88 developed by the Federal State Budget Scientific Institution "ARC "Donskoy" was used as the maternal form; the varieties Seso 1, Seso 3, and Narosorg 1 developed by the National Semi Arid Resource Research Institute (NaSARRI, Republic of Uganda) was used as the paternal forms (Figure $1)$.

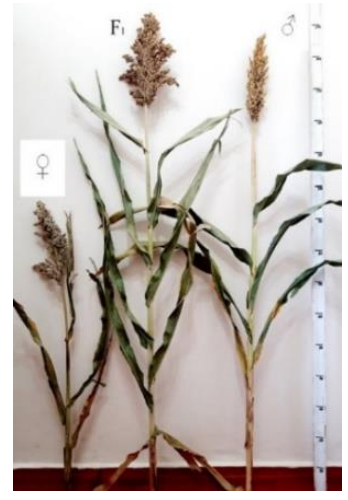

A

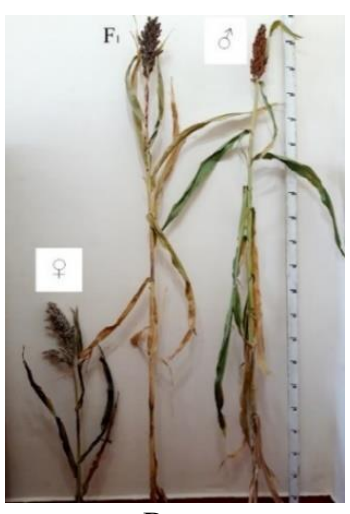

B

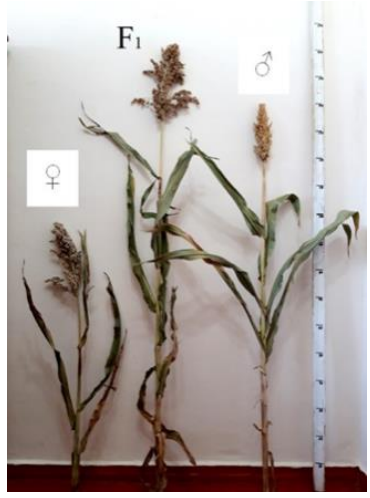

C

Fig. 1. Parental forms and the first generation hybrid: A) Zernogradskoe $88 \mathrm{x}$ Seso 1; B) Zernogradskoe 88 x Seso 3; C) Zernogradskoe 88 x Narosorg 1 . 
In the conducted study there have been made the conclusions about the nature of inheritance based on the analysis of the values of true and hypothetical heterosis, as well as the dominance degree in the first generation hybrids according to the main economically valuable traits.

In the combination Zernogradskoe 88 x Seso 1, there was overdominance of the main components of the yield structure: 1000 -grain weight $(\mathrm{hp}=3.9)$ and number of grains per panicle $(\mathrm{hp}=4.7)($ Table 1$)$.

Table 1. Dominance degree, true and hypothetical heterosis in the combination Zernogradskoe $88 \mathrm{x}$ Seso 1.

\begin{tabular}{|c|c|c|c|c|c|c|c|}
\hline Trait & $\begin{array}{c}\text { Maternal } \\
\text { form } \\
(+)\end{array}$ & $\begin{array}{c}\text { Paternal } \\
\text { form } \\
\left(\bigcup^{\Uparrow}\right)\end{array}$ & $\mathrm{P}_{\text {aver. }}$ & $\mathrm{F}_{1}$ & $\mathrm{hp}$ & $\begin{array}{c}\mathrm{H}_{\text {true, }}, \\
\%\end{array}$ & $\mathrm{H}_{\text {hyp, }} \%$ \\
\hline 1000-grain weight, g & 28.1 & 24.4 & 26.3 & 33.4 & 3.9 & 18.9 & 27.2 \\
\hline $\begin{array}{c}\text { Number of grains } \\
\text { per panicle, pc }\end{array}$ & 1825 & 2283 & 2054 & 3132 & 4.7 & 37.2 & 52.5 \\
\hline Plant height, cm & 99 & 149 & 124 & 155 & 1.2 & 4.0 & 25.0 \\
\hline $\begin{array}{c}\text { Vegetation period, } \\
\text { days }\end{array}$ & 96 & 110 & 103 & 100 & -0.4 & -9.1 & -2.9 \\
\hline $\begin{array}{c}\text { Length of a } \\
\text { peduncle, cm }\end{array}$ & 11 & 3 & 7.0 & 22 & 3.8 & 100.0 & 214.3 \\
\hline Raw protein, \% & 13.6 & 15.1 & 14.4 & 12.7 & -2.2 & -15.9 & -11.5 \\
\hline Starch, \% & 72.5 & 68.8 & 70.7 & 71.6 & 0.5 & -1.2 & 1.3 \\
\hline
\end{tabular}

There has been established manifestation of true and hypothetical heterosis according to these traits. True heterosis based on the trait ' 1000 -grain weight' was $18.9 \%$, and the hypothetical was $27.2 \%$. According to the trait 'number of grains per panicle' there was established a higher heterosis $\left(\mathrm{H}_{\text {true }}=37.2 \%, \mathrm{H}_{\text {hyp }}=52.5 \%\right)$. Despite a negative correlation between the traits '1000-grain weight' and 'number of grains per panicle' [16], it is possible to improve one trait without reducing the other [10].

This hybrid combination showed a significant (overdominance, $\mathrm{hd}=3.8$ ) improvement of the trait 'length of a peduncle' in comparison with the parental forms. The vegetation period of the hybrid Zernogradskoe 88 x Seso 1 lasted 100 days, and the trait was inherited by the type of partial dominance of early maturity.

Among the traits that determine sorghum grain quality, starch content showed semidominance of a higher value $(\mathrm{hp}=0.5)$. Moreover, protein percentage in the hybrid was lower $(12.7 \%)$ than in the initial parental forms (13.6\% in Zernogradskoe $88,15.1 \%$ in Seso 1 ). The value of true heterosis was $15.9 \%$, and the value of hypothetical heterosis was $11.5 \%$.

In the first generation combination, developed from hybridization of the varieties Zernogradskoe 88 and Seso 3, the studied traits didn't have positive manifestation of heterosis for the breeding process. The trait 'starch content' was an exception, when a slight increase in starch percentage was identified in the hybrid in relation to the original samples $\left(\mathrm{H}_{\text {true }}\right.$ and $\mathrm{H}_{\text {hyp. were }} 0.6 \%$ ) (Table 2).

Table 2. Dominance degree, true and hypothetical heterosis in the combination Zernogradskoe $88 \mathrm{x}$ Seso 3.

\begin{tabular}{|c|c|c|c|c|c|c|c|}
\hline Trait & $\begin{array}{c}\text { Matern } \\
\text { al form } \\
(\odot)\end{array}$ & $\begin{array}{c}\text { Paternal } \\
\text { form } \\
\left({ }^{\lambda}\right)\end{array}$ & $\mathbf{P}_{\text {aver. }}$ & $\mathbf{F}_{\mathbf{1}}$ & $\mathbf{h p}$ & $\begin{array}{c}\mathbf{H}_{\text {true, }}, \\
\mathbf{\%}\end{array}$ & $\begin{array}{c}\mathbf{H}_{\text {hyp }} \\
\mathbf{\%}\end{array}$ \\
\hline 1000-grain weight, g & 28.1 & 23.1 & 25.6 & 20.4 & -2.1 & -27.4 & -20.3 \\
\hline $\begin{array}{c}\text { Number of grains per } \\
\text { panicle, pc }\end{array}$ & 1825 & 2779 & 2302 & 2382 & 0.2 & -14.3 & 3.5 \\
\hline
\end{tabular}




\begin{tabular}{|c|c|c|c|c|c|c|c|}
\hline Plant height, cm & 99 & 205 & 152 & 210 & 1.1 & 2.4 & 38.2 \\
\hline $\begin{array}{c}\text { Vegetation period, } \\
\text { days }\end{array}$ & 96 & 134 & 115 & 121 & 0.3 & -9.7 & 5.2 \\
\hline $\begin{array}{c}\text { Length of a } \\
\text { peduncle, cm }\end{array}$ & 11 & 0 & 5.5 & 1.0 & -0.8 & -90.9 & -81.8 \\
\hline Raw protein, \% & 13.6 & 12 & 12.8 & 12.3 & -0.6 & -9.6 & -3.9 \\
\hline Starch, \% & 72.5 & 72.6 & 72.6 & 73.0 & 0.0 & 0.6 & 0.6 \\
\hline
\end{tabular}

The first generation hybrid Zernogradskoe $88 \times$ Narosorg 1, as well as the combination Zernogradskoe $88 \times$ Seso 1, showed a significant improvement of the value of the traits '1000-grain weight' (31.7 g), 'number of grains per panicle' (3091 pcs.) and 'length of a peduncle' $(19 \mathrm{~cm})$ compared to the initial parental forms. True heterosis according to the trait '1000-grain weight' was $12.8 \%$; according to 'number of grains per panicle' it was $62.3 \%$, and according to 'length of a peduncle' it was $72.7 \%$. Hypothetical heterosis was $17.6 \%, 65.7 \%$ and $153.3 \%$, respectively (table 3 ).

Table 3. Dominance degree, true and hypothetical heterosis in the combination Zernogradskoe $88 \mathrm{x}$ Narosog 1.

\begin{tabular}{|c|c|c|c|c|c|c|c|}
\hline Trait & $\begin{array}{c}\text { Maternal } \\
\text { form } \\
(9)\end{array}$ & $\begin{array}{c}\text { Paternal } \\
\text { form } \\
\left({ }^{\lambda}\right)\end{array}$ & $\mathbf{P}_{\text {aver. }}$ & $\mathbf{F}_{1}$ & hp & $\begin{array}{c}\mathbf{H}_{\text {true }} \\
\%\end{array}$ & $\begin{array}{c}\text { Hhyp }_{\text {, }} \\
\% \%\end{array}$ \\
\hline $\begin{array}{c}\text { 1000-grain } \\
\text { weight. } g\end{array}$ & 28.1 & 25.8 & 27.0 & 31.7 & 4.1 & 12.8 & 17.6 \\
\hline $\begin{array}{l}\text { Number of } \\
\text { grains per } \\
\text { panicle. pc }\end{array}$ & 1825 & 1905 & 1865 & 3091 & 30.7 & 62.3 & 65.7 \\
\hline $\begin{array}{l}\text { Plant height. } \\
\mathrm{cm}\end{array}$ & 99 & 141 & 120 & 162 & 2.0 & 14.9 & 35.0 \\
\hline $\begin{array}{l}\text { Vegetation } \\
\text { period. days }\end{array}$ & 96 & 112 & 104 & 102 & -0.3 & -8.9 & -1.9 \\
\hline $\begin{array}{l}\text { Length of a } \\
\text { peduncle. } \mathrm{cm}\end{array}$ & 11 & 4 & 7.5 & 19 & 3.3 & 72.7 & 153.3 \\
\hline Raw protein. $\%$ & 13.6 & 13.5 & 13.55 & 12.2 & -27.0 & -10.3 & -10.0 \\
\hline Starch. \% & 72.5 & 71.1 & 71.8 & 71.6 & -0.3 & -1.2 & -0.3 \\
\hline
\end{tabular}

There should be noted the manifestation of negative heterosis in protein and starch content in the grains of the combination Zernogradskoe 88 x Narosorg 1.

The plant height in all three hybrid combinations exceeded that of the parental samples, that is, there was overdominance of the trait $(\mathrm{hp}=1.1-2.0)$. It is worth noting that the maternal form Zernogradskoe 88 was a low-growing variety $(99 \mathrm{~cm})$, while the paternal varieties from Uganda (Seso 3) were tall-growing $(141-205 \mathrm{~cm})$. Similar conclusions about the overdominance of tall-growing forms were made in the work of Kovtunova et al. $[1]$.

\section{Conclusions}

1. In the hybrids of the variety Zernogradskoe 88 as a maternal form with the varieties Seso 1 and Narosorg 1 used as paternal forms, there was identified overdominance, as well as significant true and hypothetical heterosis in terms of the trait'1000-grain weight' (hp=3.9 $\left.4.1 ; \mathrm{H}_{\text {true }}=12.8-18.9 \% ; \mathrm{H}_{\text {hyp }}=17.6-27.2 \%\right)$, 'number of grains per panicle' $(\mathrm{hp}=4.7-$ $\left.30.7 ; \mathrm{H}_{\text {true }}=37.2-62.3 \% ; \mathrm{H}_{\text {hyp }}=52.5-65.7 \%\right)$ and 'length of a peduncle' (hp=3.3 - 3.8; $\mathrm{H}_{\text {true }}=72.7-100 \%$; $\mathrm{H}_{\text {hyp }}=153.3-214.3 \%$ ).

2. Inheritance of the vegetation period in the studied combinations corresponded to the partial dominance of both lower $(\mathrm{hp}=-0.3--0.4)$ and large values of the trait $(\mathrm{hp}=0.3)$. 
3. According to the trait 'plant height' in all combinations, there was identified overdominance of tall-growing forms $(\mathrm{hp}=1.1-2.0)$.

4. Protein percentage in sorghum grain is inherited according to the type of dominance of lower values of the trait $(\mathrm{hp}=-0.6)$ or depression $(\mathrm{hp}=-2.2--27.0)$.

5. There was no significant starch increase in the identified hybrids in comparison with the parental forms $\left(\mathrm{H}_{\text {true }}=-1.2-0.6 \% ; \mathrm{H}_{\mathrm{hyp}}=-0.3-1.3 \%\right)$.

\section{References}

1. N. Kovtunova, V. Kovtunov, A. Popov, E3S Web of Conferences 175, 01012 (2020) https://doi.org/10.1051/e3sconf/202017501012

2. R. Mohammed, A. Are, R. Bhavanasi et al., Front. Plant Sci. 6, 1-17 (2015) doi: 10.3389/fpls. 2015. 00945

3. R. Boyles, Z. Brenton, S. Kresovich, The Plant Journal 97, 19-39 (2019) doi: 10.1111/tpj.14113

4. D. Ng'uni, M. Geleta, Per Hofvander et al., AJCS 6(1), 56-64 (2012)

5. D. Fano, International Journal of Agriculture Sciences 43(9), 4702-4707 (2017)

6. B. Fantaye, J. Advan. Plant Sci. 1, 307 (2018)

7. Rebecca Murphy, Robert Klein, Daryl Morishige et al., Proc. Natl. Acad. Sci. USA 108, 16469-16474 (2011) DOI: 10.1073/pnas.1106212108

8. R. Klein, F. Miller, D. Dugas, P. Brown et al., Theor. Appl. Genet 128, 1669-1683 (2015) DOI: 10.1007/s00122-015-2523-z

9. A. Schaffasz, S. Windpassinger, W. Friedt, R. Snowdon, B. Wittkop, Agronomy 9(9), 535 (2019) https://doi.org/10.3390/agronomy9090535

10. R. Boyles, E. Cooper, M. Myers et al., Plant Genome 9, 1-17 (2016) doi:10.3835/plant-genome2015.09.0091

11. Y. Tao, E. Mace, B. George-Jaeggli et al., Plant Genome 11(2), 170089 (2018) doi:10.3835/plantgenome2017.10.0089.

12. D. Zhang, W. Kong, J. Robertson et al., BMC Plant Biology 15, 107 (2015) DOI 10.1186/s12870-015-0477-6

13. Miki Yamaguchi, Haruka Fujimoto, Ko Hirano et al., Scientific Reports 6, 28366 (2016) DOI: $10.1038 /$ srep28366

14. D. Rhodes, L. Hoffmann Jr., W. Rooney et al., BMC Genomics 18, 15 (2017) doi: 10.1186/s12864-016-3403-x

15. M. Mofokeng, H. Shimelis, M. Laing, AJCS 11(02), 142-148 (2017) doi: 10.21475/ajcs.17.11.02.p127

16. G. Burow, Zh. Xin, C. Hayes, J. Burke, Crop Sci. 54, 2030-2037 (2014) doi: 10.2135/cropsci2013.08.0566 